\title{
The Development Process of a Mathematic Teacher's Technological Pedagogical Content Knowledge *
}

\author{
Hilal Yildiz ** \\ Kafkas University, TURKEY
}

\author{
Tuba Gokcek \\ Kirikkale University, TURKEY
}

Received: July 31, 2017 - Revised: October 13, 2017 • Accepted: November 10, 2017

\begin{abstract}
Technology is an indispensable part of the educational curriculum, and large budgets have been allocated to provide technological infrastructure in secondary education institutions in Turkey. It is important that teachers have the technological pedagogical content knowledge (TPCK) to successfully integrate technology into their courses. The aim of this study is to examine the development of the TPCK of a mathematics teacher who participated in in-service training course organized for the use of Geogebra software in geometry teaching. The in-service training is designed in accordance with the Technology Integration Model stages, and Geogebra software is used taking into account the learning outcomes of 9 th and 10th grade secondary school geometry. The case study method has been employed, and data was collected through interviews, observation, self-assessment forms, and field notes. The findings show that the in-service training helped the maths teacher integrate technology in the teaching and developed the knowledge of curriculum, students' understandings and learnings, and instructional strategies and methods. With regard to research recommendations and results, professional development programs that will provide TPCK development can be organized so that teachers can use the ever-evolving technologies in their classes along with the appropriate pedagogical approaches.
\end{abstract}

Keywords: Technological pedagogical content knowledge (TPCK), in-service training, Geogebra, teaching geometry.

To cite this article: Yildiz, H., \& Gokcek, T. (2018). The development process of a Mathematic teacher's technological pedagogical content knowledge. European Journal of Educational Research, 7(1), 9-29. doi: 10.12973/eu-jer.7.1.9

\section{Introduction}

The technological developments which affect many areas in our life also influence the field of education. The introduction of information and communication technologies into the education system has led to drastic changes in the education and training processes and the curriculum design. These changes led to moving away from teaching that is based on passive learning (Ergun, 1989; Numanoglu, 1992).

The Turkish Ministry of National Education (MONE) has been working on the integration of technology in formal education since 1984 (Sezer, 2011; Usun, 2013). The latest work in this field has been the introduction of the "Movement to Increase Opportunities and Technology in Education" project (also known as the FATIH Project). Within the scope of FATIH Project, all primary and secondary schools were provided with interactive smart boards, tablet computers, and internet network infrastructure.

The components of the FATIH project are the provision of hardware and software infrastructure, the provision and management of educational e-content, the use of effective information technology in curricula, the in-service training of teachers, and the use of secure, manageable, and measurable information technologies (Egitim Reformu Girisimi [ERG], 2014; URL-1).

The use of effective information technology in the curriculum as well as technological equipment is important for technology integration. Mathematics curricula in various countries refer to the necessity and importance of integrating technology into the teaching of mathematics (NCTM, 1989, 1991, 2000; Ozkan, 2006; Guzel, 2010). In Turkey, in 2013, the geometry and mathematics courses were combined into a single teaching unit along the guidelines of the "Teaching Program for Secondary Mathematics Teaching", and the use of dynamic geometry software has been proposed so that students can benefit from information and communication technologies and can learn and discover geometric relationships in a more efficient way (MONE, 2013). In parallel with the new curriculum for secondary school mathematics in 2013, school textbooks have also been revised and the textbooks included various activities based on the Geogebra software.

\footnotetext{
* The present study was conducted as the PhD thesis of Hilal Yildiz.

** Corresponding author:

Hilal Yildiz , Kafkas University, Mathematics Education Department, Turkey.

Email: hilalaslanbas@hotmail.com
} 
The hardware and software provided by the FATIH project, the existence of a curriculum that suggests technology integration is not enough for teachers to integrate technology into classroom practices. Teachers who plan and implement the use of technology within the classroom are an important component of technology integration. It is not enough to know the technical details of how to use the available technological tools to use them effectively in the teaching process. Teachers should be able to integrate the technology with their subjects (Baki, 2001; Earle, 2002) and should know how to combine the use of technology with an appropriate pedagogical approach (Niess, 2005; Bozkurt and Cilavdaroglu, 2011).

Technological pedagogical content knowledge (TPCK) which is defined as knowledge of how to use technology for an effective teaching of a specific subject is a competency that a teacher should possess for successful technology integration (Mishra and Koehler, 2006; Demir and Ozmantar, 2013). TPCK is also included in the Ministry of National Education's projects and list of core teacher competencies (MONE, 2011, 2016).

The studies demonstrate that teachers need professional development programs that focus on the practical application of technology, content and pedagogy interactions so that they can effectively integrate technology into their lessons (Niess et al., 2010; Demir and Bozkurt, 2011; Kaleli-Yilmaz, 2012; Keles and Celik, 2013; Yadigaroglu, 2014).

\section{Theoretical Framework}

TPCK, which is regarded as the competence that teachers and prospective teachers should have in order to integrate technology into the teaching process, was introduced as a concept by Mishra and Koehler (2006) adding technological knowledge to Shulman's (1986) model of pedagogical knowledge. TPCK requires being able to explain concepts using technology, knowing the pedagogical techniques that use technology in a constructive way and in accordance with the needs of students. It also requires knowledge of what makes concepts difficult or easy to learn and how technology can help teachers to address some of the problems that students face; as well as knowledge of students' prior and epistemological beliefs and knowledge of how to use technology to build on existing knowledge developing new epistemologies or to strengthen previous epistemologies (Mishra and Koehler, 2006).

The TPCK theoretical framework suggested by Mishra and Koehler (2006) has been the subject of many studies. When the literature is examined, it can be seen that the researchers identify the components of TPCK models by integrating technology into the PCK models. Table 1 presents the PCK models that researchers use when they develop the TPCK model.

Table 1. PCK components used by researchers when developing TPCK model

\section{Types of knowledge accepted as components of PCK}

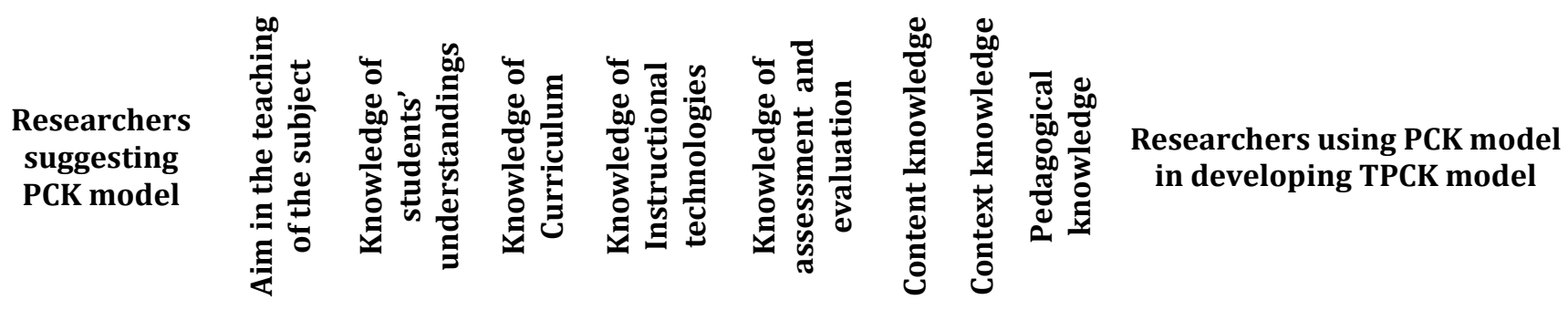

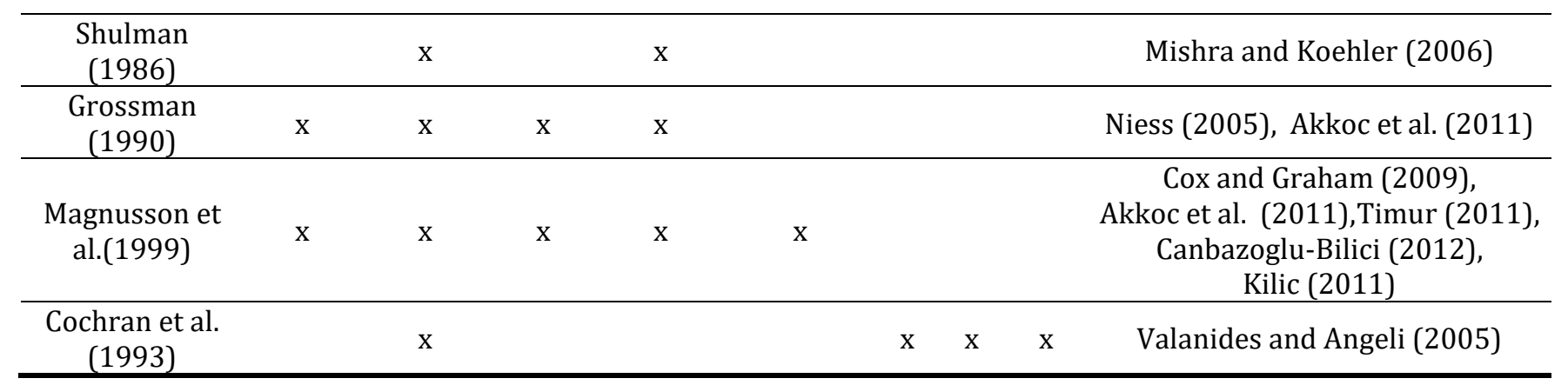

Niess (2005) and Akkoc et al. (2011) examined the TPCK of student teachers in a mathematics teacher preparation program that integrated teaching and learning with technology throughout the program. Therefore within the context of this research, the TPCK components suggested by Niess (2005) and Akkoc et al. (2011) who used dynamic geometry software for geometry teaching are identified as follows:

Teaching geometry by integrating technology in the learning: Magnusson et al. (1999) argues that Grossman's (1990) beliefs and knowledge about the aim of teaching specific topics which he identified as a component of the PCK can be named as adaptation in science teaching. Adapting the teaching of geometry using technology refers to teachers' beliefs and knowledge about how geometry teaching can be supported by technology (Niess, 2005) and the disadvantages that 
technology can bring. This knowledge and these beliefs lead the teachers to take various steps in order to use technology in teaching geometry.

Knowledge of Curriculum that integrate technology with teaching geometry: Niess (2005) defined the TPCK components for mathematics teachers by adapting Grossman's (1990) PCK components to the use of technology in the class. Curriculum material knowledge is the teacher's knowledge of the curriculum and the curriculum resources that integrate technology in the teaching of a subject. The teacher knows how to use technology in teaching the curriculum as well as how to access the curriculum resources.

Knowledge of students' understandings and learnings with technology in geometry: Grossman (1990) uses Magnusson et al.'s (1999) concept of knowledge of students' understanding which is classified as a component of PCK. In the context of TPCK, this component contains teachers' knowledge about the students' prior knowledge on a particular topic, learning difficulties and misconceptions and about the technological tools that can be used to identify and address these difficulties. The teacher prepares the lesson plan taking these into consideration and executes the lesson (Akkoc et al., 2011).

Knowledge of instructional strategies and methods for teaching geometry with technology: This component is about teachers' adaptation of the various technological tools related to the teaching of science/mathematics to the teaching objectives and needs of learners (Niess, 2008). The teacher can design technology-aided learning environments appropriate to different teaching methods and strategies and can accordingly apply in practice the designed scenarios (Akkoc et al., 2011).

When the studies on TPCK are examined, it is seen that the number of development, scale adaptation and survey studies are in a great number, and qualitative studies examining TPCK development of teachers and teacher candidates are few. It is observed that studies conducted with qualitative and mixed methods are mostly studied with teacher candidates (Akkoc et al., 2011, Kaleli-Yilmaz, 2015; Voogt et al., 2013). In this study, the TPCK development of the secondary school mathematics teacher will be examined, adding to the originality of the study. Studies in the literature appear to have begun to focus on TPCK competencies on specific topics from a general TPCK competence level (Canbazoglu-Bilici, 2012; Timur, 2011; Saralar, 2016). This study focused on the development TPCK related to the geometry in high school.

In this study, an in-service training course was designed for the use of Geogebera software in teaching high school geometry. It is aimed to examine the TPCK development of a mathematics teacher participating in the in-service training course. In this context, the study seeks answers to the following main and sub questions:

How does the in-service training course affect the development of TPCK on geometry of the mathematics teacher?

1. How does the teacher's teaching geometry by integrating technology in the learning change?

2. How does teacher's knowledge of curriculum that integrate technology with teaching geometry change?

3. How does teacher's knowledge of student understandings and learnings with technology change?

4. How does teacher's knowledge of instructional strategies and methods for teaching geometry with technology change?

\section{Methodology}

The study was conducted in two phases. In the first phase of the research, a literature review is conducted to identify teachers' integration of technology into maths classes and the in-service training needs oriented to the TPCK model. Subsequently, a number of semi-structured interviews with teachers were conducted. In accordance with the identified needs, an in-service training is designed based on the Technology Integration Model (Bozkurt et al,. 2013). In the second phase of the study, the designed training was offered to teachers in the computer laboratory of a secondary school in Kars, and the TPCK development of a mathematics teacher was accordingly tracked and monitored.

In this part of the study, design of research, sample, data collection tools, data analysis, the structure and content of inservice training are presented.

\section{Design of Research}

A qualitative case study methodology was employed in this research. The case study methodology allows an in-depth investigation of several special cases through multiple sources of information (observation, interviews, documents, etc.) (Creswell, 2013). The study also uses the holistic one-state design pattern and examines the TPCK development of a mathematics teacher by means of multiple data collection tools. In the research, the TPCK development of a mathematics teacher was investigated in terms of components of i) Teaching geometry by integrating technology in the learning ii) Knowledge of Curriculum that integrate technology with teaching geometry iii) Knowledge of students' understandings and learnings with technology in geometry and iv) Knowledge of instructional strategies and methods for teaching geometry with technology. 
The sample of the study includes a high school mathematics teacher who participated in in-service training for the use of Geogebra software in geometry teaching. The teacher was working at a high school in Kars ${ }^{\dagger}$ at the time of the research. Table 3 presents a short profile of the teacher.

Table 2. Profile of the teacher (Melis)

\begin{tabular}{ll}
\hline Graduation & Faculty of Science and Literature \\
\hline Age & 28 \\
\hline Teaching experience & 4 years \\
\hline IT training at high school & Basic IT course \\
\hline IT training at university & Basic IT Course \\
\hline & -Basic Computer use \\
Technology oriented in- & -Interactive Board \\
service training & -EBA (Education Information \\
& Network) Seminar \\
\hline
\end{tabular}

The mathematics teacher who participated in the study is a graduate of the Faculty of Science and Literature. She is 28 years old and has 4 years of professional experience. The teacher has a basic knowledge of computers, she has learned to use interactive boards in in-service trainings within the context of the FATIH Project, and she has participated in the EBA (Education Information Network) seminars to learn about the e-contents included in the FATIH Project. The school in which the teacher works has an interactive board in every class while the tablets distributed within the scope of FATIH Project were only given to 10th grade students. The observation of this teacher's activities took place, therefore, in her 10th grade eleven classes.

Data Collection Tools

The data of this study was collected through observation, interviews, self-assessment forms, and field notes.

\section{Interviews}

A semi-structured interview was used to investigate the teacher's TPCK components before and after the in-service training. The interview questions were prepared according to TPCK components drawn from the literature. Expert opinions were also taken into account while forming the interview questions. Prior to in-service training, interview was conducted to identify teachers and determine the current status of TPCK's integrating technology in the learning, understanding of the students, curriculum knowledge, and instructional strategies and methods in the teaching of geometry components. After the in-service training, the teacher was interviewed to reveal the development of these components.

The questions were examined by a computer technology teacher who worked for the FATIH Project in-service training courses to check whether there were any ambiguous questions. Additional questions were asked to the teacher during the interview. Interviews usually lasted between 35 and 40 minutes. The required consent was taken and the interviews were tape-recorded.

\section{Observation}

In this study, the non-participant observation method was used in natural classroom environment. The teachers and students who were observed were informed why the researcher was there. The researcher performed the observation by sitting in an appropriate empty space in the class and video-recorded the class with the permission of the teacher. In this regard, it was possible to examine afterwards the data in detail.

The aim of the observations was to measure the performance of the teacher on the understanding of the student, curriculum knowledge, and instructional strategies and methods in the teaching of geometry. A fixed observation form was not used during the observations, and the video recordings were examined later within these components. In particular, these components of TPCK were examined before, during, and after the monitoring and evaluation process of the in-service training.

Observations were conducted for a total of 11 hours; 1 hour before the in-service training, 1 hour during the training, and 9 hours after the training.

\section{Self-Assessment Form}

A self-assessment form consisting of open-ended questions was prepared by the researcher. The teacher was asked to explain learning outcome, technology, planning, implementation, and evaluation phases in this form. Some of the questions in the form are: "What did you consider when planning your lesson?", "For what purpose did you use Geogebra software?", "What teaching strategies and methods did you use?", "Did you succeed in practice?". Expert

\footnotetext{
† Kars is a city in northeast Turkey
} 
opinions were taken into account while forming the questions. A computer technology teacher who was in charge of the FATIH project in-service training courses checked whether the questions in the form were intelligible.

A self-assessment form was used for the teacher to assess herself and her classroom practice during the in-service training process. During the last face-to-face session of the in-service training course, the teacher watched the video in which she was using the Geogebra software in geometry teaching for the first time. Thus, the teacher was able to monitor her practice and to respond accordingly and in writing to the questions on the self-evaluation form.

\section{Field Notes}

Within the scope of this study, the researcher visited the teacher in the school where she was working, provided technological support, and observed the classroom practices. During the school visits the researcher took notes on a number of interesting issues, the informal dialogues held with the teacher, and the classroom practices.

\section{Data Analysis}

Descriptive analysis and content analysis techniques were used in the analysis of qualitative data obtained through the interview, the observation, the self-assessment form, and the field notes. According to the scope of the research, qualitative data analysis may include both inductive and deductive processes (Patton, 2014).

Before starting the analysis of the data, the interviews were transcribed, the video records of the course observations were transferred to a computer environment, and the self-evaluation forms were scanned and transferred to a computer. The Interview transcripts, observation video recordings, and self-assessment forms were analysed by a qualitative data analysis software, MAXQDA 12. The field notes kept during school visits were analysed through a descriptive analysis, the exemplary cases of the TPCK components were identified, and the explanations of steps taken by the teachers in their practice were also determined.

The content analysis of this study is based on the general framework of coding of Strauss and Corbin (1990) which requires the use of both inductive and deductive approaches. In this study, the TPCK theoretical framework and its components were determined during the descriptive analysis, and the main themes were revealed by the researcher. In particular, the following main themes were identified: teaching geometry by integrating technology in the learning; knowledge of instructional strategies and methods for teaching geometry with technology, knowledge of curriculum that integrate technology with teaching geometry and knowledge of students' understandings and learnings with technology in geometry. Subsequently, a number of studies in the literature (Niess, 2005; Baki, 2012; Akkoc et al., 2011; Timur, 2011; Kaleli-Yilmaz, 2012) were examined and subthemes and codes were analysed, and thus a framework for the analysis was established. The data from the interviews and the observation was coded according to this framework, and the themes generated during the analysis were combined with the first list.

Data collection tools used in conjunction with the theme are shown in Table 3.

Table 3. Data Collection Tools Used by Theme

\begin{tabular}{|c|c|c|c|c|}
\hline \multirow{2}{*}{$\begin{array}{l}\text { TPCK Components } \\
\text { (main themes) }\end{array}$} & \multicolumn{4}{|c|}{ Data Collection Tools } \\
\hline & Interviews & Observation & $\begin{array}{l}\text { Self-Assessment } \\
\text { Form }\end{array}$ & $\begin{array}{c}\text { Field } \\
\text { Notes }\end{array}$ \\
\hline $\begin{array}{l}\text { teaching geometry by integrating technology in } \\
\text { the learning }\end{array}$ & $\mathrm{x}$ & & & $\mathrm{x}$ \\
\hline $\begin{array}{l}\text { knowledge of curriculum that integrate } \\
\text { technology with teaching geometry }\end{array}$ & $\mathrm{x}$ & $\mathrm{x}$ & $\mathrm{x}$ & $\mathrm{x}$ \\
\hline $\begin{array}{l}\text { knowledge of students' understandings and } \\
\text { learnings with technology in geometry }\end{array}$ & $\mathrm{x}$ & $\mathrm{x}$ & $\mathrm{x}$ & $\mathrm{x}$ \\
\hline $\begin{array}{l}\text { knowledge of instructional strategies and } \\
\text { methods for teaching geometry with technology }\end{array}$ & $\mathrm{x}$ & $\mathrm{x}$ & $\mathrm{x}$ & $\mathrm{x}$ \\
\hline
\end{tabular}

For instance, the subthemes that will be presented and discussed under the category of knowledge of instructional strategies and methods for teaching geometry with technology include the teaching strategies used by the teacher, the teaching methods employed by the teacher, and the teacher's use of technology in the classes. The teaching strategies used by the teacher and the codes related to the teaching methods employed by the teacher came up as a result of the content analysis of the data. The codes related to the sub-theme of teacher's level of technology use in class are based on the themes proposed by Hughes (2005) and reorganized by Kaleli-Yilmaz (2012). The levels of technology use are listed below.

Level-0: This is about technological tools that have never been used or that do not serve specific purpose.

Level-1 (Replacement): This level is about carrying out an action with the help of technology in order to change the environment. Some examples of such actions include the use of interactive electronic books on the screen and 
providing explanations on the screen, reflection exercises or problems that can be written on the electronic board, and explaining the answers and solving the problems or questions on the screen.

Level-2 (Amplification): It is the level at which technology is used for the quick and effective execution of the learning process. The ability of acquiring prior knowledge about the subject more quickly and effectively, quickly revising prior knowledge, and using software to demonstrate the learned information are examples of this level.

Level-3 (Transformation): Unlike traditional practices, it is the level where concepts are used to encourage studentcentred explorations and a deep conceptual understanding.

The video recordings of the observed classes were analysed in detail, the time intervals at which the different themes emerged were determined, and each level was calculated in percent of the course duration and presented with graphics.

The research data was also coded by a second researcher who had worked in the TPCK field. The coding reliability was calculated through the following formula: the number of agreements is divided by the total number of agreements and disagreements (Miles and Huberman, 2015). It is necessary to reach a confidence level of at least 0.70 for coding reliability (Yildirim and Simsek, 2013). In this study, coding reliability was determined as 0.83 .

\section{The structure and content of in-service training}

The course was designed according to the Technology Integration Model (Bozkurt et al,. 2013). The stages of this model are included in the Table 4.

Table 4. Stages of Technology Integration Model

\begin{tabular}{ll}
\hline Stage & Explanation \\
\hline $\begin{array}{l}\text { Learning } \\
\text { Outcome }\end{array}$ & $\begin{array}{l}\text { The content of the learning outcome to be taught must be analyzed. What difficulties do students } \\
\text { have in this learning outcome? How to use the technologies to be used in teaching this } \\
\text { achievement and overcoming student difficulties should be considered. }\end{array}$ \\
\hline \multirow{2}{*}{ Technology } & $\begin{array}{l}\text { Knowing the technology and knowing its proper use has four dimensions. These include (1) } \\
\text { knowing the technical specifications of the technology; (2) knowing the possibilities of } \\
\text { technology; (3) knowledge of the constraints of technology; (4) have pedagogical knowledge } \\
\text { about the use of technology. }\end{array}$ \\
\hline \multirow{2}{*}{ Planning } & $\begin{array}{l}\text { In this phase, classroom practices are planned. When planning for the courses in which the } \\
\text { technology is included, it should be decided on the technology usage scenario and the level of } \\
\text { technology usage and alternative planning should be done for unexpected situations. }\end{array}$ \\
\hline \multirow{2}{*}{ Emplementation } & $\begin{array}{l}\text { It is the phase in which the plans developed are being passed on. Attention should be paid to the } \\
\text { right of directing the events, the inclusion of the students in the process, and the management of } \\
\text { the students' attention. }\end{array}$ \\
\hline \multirow{2}{*}{$\begin{array}{l}\text { The assessment here is not relevant to the situation of the students. The evaluation stage is to } \\
\text { receive feedback on the technology integration process. Here the teacher makes a self- } \\
\text { assessment on the use of technology. }\end{array}$} \\
\hline
\end{tabular}

The course included 21 hours of training during 7 days. The course was offered in the spring term of the 2014-2015 academic year. The face-to-face sessions on learning outcome, technology, planning and implementation phases lasted 6 days. Two days a week training was given. The details of the training for these stages in the first three weeks are included in the Table 5. After the third week of training, the teacher used the Geogebra software for the first time in implementation stage of the course and the lesson was recorded in the video recording. This video recording was later analysed in the evaluation phase and the classes were similarly observed and monitored. During and after the training the researcher visited the teacher in the school where she was working and provided technological support.

The use of Geogebra software has been explained through ready Geogebra materials developed by the researcher to prevent the training from being boring and to allow the teachers to see how the product works in practice. The Geogebra materials were designed according to the 9 th and 10th grade geometry learning outcomes related to the use of ICT which are included in the secondary school mathematics curriculum. In addition, each stage of the Technology Integration Model was exemplified using lesson plans and class videos. The in-service training course includes activities that will enable the teacher to experiment with Geogebra material like a student and to experience a discovery process. The table below contains the content and calendar of the in-service training. 
Table 5. The content and calendar of in-service training course

\begin{tabular}{|c|c|c|c|}
\hline WEEK & DAY & $\begin{array}{l}\text { The phase of } \\
\text { Technology } \\
\text { Integration } \\
\text { Model }\end{array}$ & In-service training content \\
\hline \multirow{3}{*}{ WEEK 1} & \multirow[t]{2}{*}{$\begin{array}{l}\text { March } 3^{\text {rd }}, 2015 \\
\quad(3 \text { hours })\end{array}$} & $\begin{array}{l}\text { Learning } \\
\text { Outcome }\end{array}$ & $\begin{array}{l}\text { - Talking about technology as one of the competencies that a } \\
\text { teacher should hold } \\
\text { - Introduction of TPCK model } \\
\text { - Analysing secondary school mathematics curriculum and } \\
\text { discussing how the curriculum should be delivered and the } \\
\text { materials of the curriculum }\end{array}$ \\
\hline & & Technology & $\begin{array}{l}\text { - Introducing Geogebra software } \\
\text { - Installing the software } \\
\text { - Introducing the interface and tools of Geogebra } \\
\text { - Use of Geogebra with sample materials }\end{array}$ \\
\hline & $\begin{array}{l}\text { March } 4^{\text {th }}, 2015 \\
\quad(3 \text { hours })\end{array}$ & Technology & $\begin{array}{l}\text {-Use of Geogebra with sample materials } \\
\text { - Using menu tools } \\
\text { - Experimentation of teachers with materials on student roles }\end{array}$ \\
\hline \multirow[b]{2}{*}{ WEEK 2} & $\begin{array}{l}\text { March } 10^{\text {th }}, 2015 \\
\quad(3 \text { hours })\end{array}$ & $\begin{array}{l}\text { Technology/ } \\
\text { Planning }\end{array}$ & $\begin{array}{l}\text { - Use of Geogebra with sample materials } \\
\text { - Presentation and Discovery Technique } \\
\text { - Napoleon's thereom } \\
\text { - Discussing which teaching strategy can accompany } \\
\text { Geogebra material. }\end{array}$ \\
\hline & $\begin{array}{l}\text { March, } 11^{\text {th }} 2015 \\
\quad \text { (3 hours) }\end{array}$ & $\begin{array}{l}\text { Technology/ } \\
\text { Planning }\end{array}$ & $\begin{array}{l}\text { - Use of Geogebra with sample materials } \\
\text { - The principles that should be taken into account when } \\
\text { planning activities supported by technology } \\
\text { - TASK: Teachers should identify a learning outcome and } \\
\text { design a material accordingly. They should also plan how to } \\
\text { use the material in the class. }\end{array}$ \\
\hline \multirow[b]{2}{*}{ WEEK 3} & $\begin{array}{l}\text { March } 17^{\text {th }}, 2015 \\
\quad(3 \text { hours })\end{array}$ & Planning & $\begin{array}{l}\text { - Presentation of the materials designed by teachers } \\
\text { - Discussion of the lesson plans } \\
\text { - Researcher's presentation of the material and explanation of } \\
\text { learning outcomes, technology and planning phases. }\end{array}$ \\
\hline & $\begin{array}{l}\text { March } 18^{\text {th }}, 2015 \\
\quad(3 \text { hours })\end{array}$ & Implementation & $\begin{array}{l}\text { - Presenting different implementations that make a difference } \\
\text { in teaching and learning process. } \\
\text { - Watching a sample implementation video-recorded by the } \\
\text { researcher } \\
\text { - Discussion } \\
\text { TASK: Teachers will video-tape their use of Geogebra } \\
\text { materials in their own classes. }\end{array}$ \\
\hline WEEK 4 & $\begin{array}{l}\text { May } 3 \text { rd }, 2015 \\
\quad(3 \text { hours })\end{array}$ & Evaluation & $\begin{array}{l}\text { - Self-reflection and evaluation of teachers on their videos. } \\
\text { - Discussion on teachers' experiences. }\end{array}$ \\
\hline
\end{tabular}

\section{Findings}

This study focused on the professional development of the mathematics teacher during the in-service training course which was mainly designed to improve the technological pedagogical content knowledge related to geometry. To this end, the research focused on the following components of TPCK: the adaptation of geometry teaching with the use of technology, curriculum knowledge, knowledge about students, and knowledge about instructional strategies and methodologies.

The teacher was anonymised as Melis when the findings were presented. In addition, the teacher was named as Melis-b in the interviews before the in-service training, and the pseudonym was changed to Melis-a in the quotations after the training.

\section{Teaching Geometry by Integrating Technology in the Learning}

In this component, interviews and field notes were used to understand the knowledge and beliefs that the teacher holds about technology. The component is presented under the two themes of "advantages of technology" and "disadvantages 
of technology". In the schematic display of codes, advantages are showing in white whereas disadvantages are shown in black.

Before the in-service training, Melis stated that the use of technology in teaching geometry visually enriches the lesson, attracts the attention of the students, provides a better understanding of the subject, and facilitates deep learning. However, she noted that there is no sufficient time for the use of technology in teaching geometry in the class and that she preferred not to use technology due to technical difficulties. The schematic representation of the teacher's views before the in-service training is shown in Figure 1.

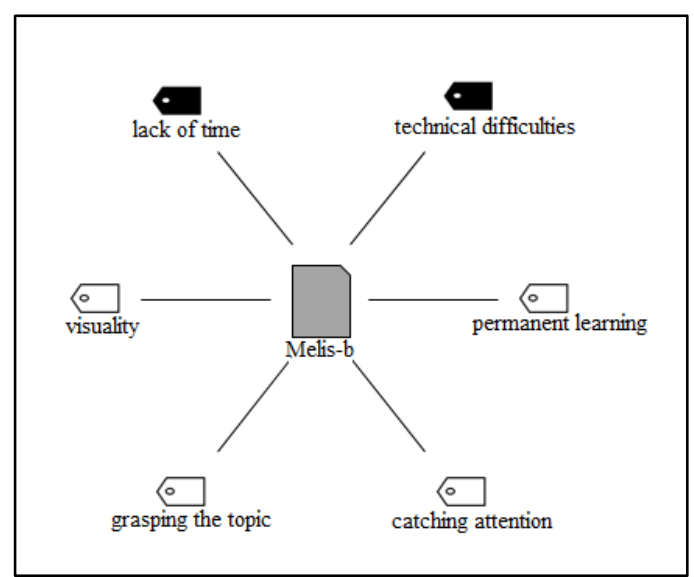

Figure 1. Melis' views regarding the advantages and disadvantages of using technology before the in-service training

The technologies that Melis mentions when she talks about the use of technology are the materials she came across at the EBA seminar. The teacher noted that the use of such technologies is beneficial but she cannot use them because of time constraints:

It is definitely a more effective way of learning. I think the constructivist approach is something that really needs time. I also wish to apply it by using in-class exercises in an effective way or using different methods. However, due to time concerns, we ignore most of these things. Yet, teaching may be more effective with these approaches. When I think about the subjects that I need to cover and the limited time I have, I ignore the bit on how I can effectively teach (Melis-b).

After the in-service training, Melis stated that when technology is used in the teaching of geometry, it visually enriches the class, attracts the attention of students, increases their participation and self-confidence, helps them better grasp the topic, eases deep learning, and creates an attractive learning environment. In the light of such positive atmosphere in the classroom environment, she also argues that teacher's professional satisfaction also increases. The schematic representation of the teacher's views after the in-service training is shown in Figure 2.

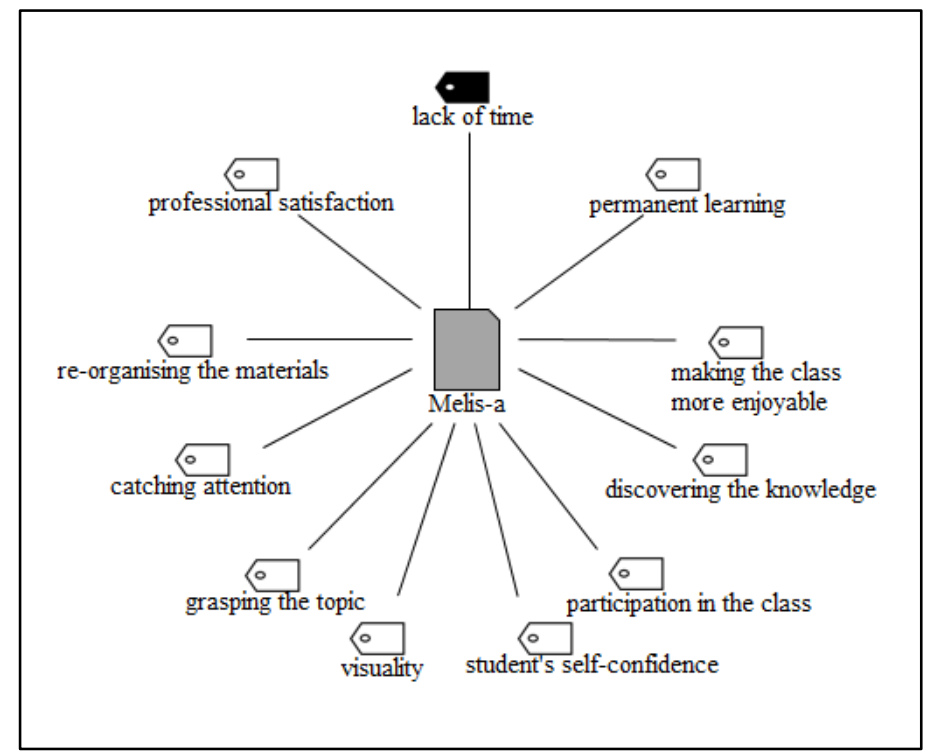

Figure 2. Melis' views regarding the advantages and disadvantages of using technology after the in-service training 
The use of the technology Melis mentions allows students to use Geogebra materials on their tablets. She stressed that the ability to reuse Geogebra materials after the changes introduced by the teacher provides a great advantage compared to the materials in the EBA system. She also added that Geogebra materials allow students to explore knowledge in a more active way.

When students discovered the knowledge themselves, I think their self-confidence increased. They said 'Yes, I can also access knowledge and explore it in a direct way. Okay, the teacher provides us with knowledge but we can also discover this on our own.' I think it was a very different experience for them (Melis-a).

The students who usually exclude themselves from the class had also a very different reaction in terms of participation which surprised me (Melis-a).

We did not have such a chance in EBA. Geogebra is dynamic, you cannot intervene in EBA, but even a student's question can help you direct the activities of Geogebra accordingly. In other words, you can add any activity you wish (Melis-a).

Despite all these positive comments, Melis still has a concern regarding inadequate time for the use of technology in geometry teaching.

Maybe it would be better if there were more classes. If the use of technology is suggested, I think that more flexibility is needed in terms of timetabling. Time is the only problem that concerns me. For example, which one is better? To teach a subject in three weeks instead of two weeks or to teach the subject in a rush? In the former case students' learning will be deeper compared with the latter case where students may more easily forget what they learned in class. I often think about this dilemma (Melis-a).

\section{Knowledge of Curriculum that Integrate Technology with Teaching Geometry}

This component includes the teacher's knowledge regarding the new mathematics curriculum and the recommended resources as well as the interviews, observations, field notes, and self-assessment forms which are employed to examine the use of these resources in the class. The sub-themes of the component are identified as follows: "the time of the last change of the teaching program, "the positive aspects of combining the topics of mathematics and geometry", "the negative aspects of combining mathematics and geometry topics", "the technological tools and software recommended by the curriculum", "the resources used in the course work", "the materials used in the course work ", "technological tools used in the course work ", and "taking the learning outcomes into account in course work."

Melis noted in the interviews conducted before and after the in-service training that she was aware of the time of the last change in the curriculum and knew that mathematics and geometry topics were combined in the secondary school mathematics curriculum. Before the in-service training, Melis said that combining the topics was good in terms of ensuring the relationship between geometry and mathematics topics and in terms of preventing geometry being perceived as a course separate from mathematics. However, she said that the time allocated for the new curriculum is insufficient. She expressed similar views after the training. Below is a quote from the interview made before the inservice training.

There is not enough time for some topics in the 9th and 10th classes but at least the geometry is no longer seen as something different. Integrating mathematics and geometry is a good idea. It is more effective to teach students the square root and then show them how to calculate the root in the triangle. So, it is nice if mathematics and geometry follow each other (Melis-b)

Melis stated that she had no idea about the technological tools and software proposed by the curriculum before the inservice training. She added that after the training, she became aware that the use of tablets and interactive boards was suggested in the curriculum, Geogebra activities were included in the textbooks, and the use of materials in the EBA system was suggested by Ministry of National Education:

I did not know beforehand that there were Geogebra activities in the book. I gained the awareness after this training (...) If a student had come and asked about an activity, I could not even give a respond (Melis-a).

The findings of the Melis teacher in relation to the sources, materials, the technological tools she uses in her classes, and how he considers the learning outcomes of the subject in the course content are given in Table 6. 
Table 6. The sources, materials, technological tools, and learning outcomes that Melis uses in her class

\begin{tabular}{|c|c|c|c|c|c|c|c|c|c|c|c|c|}
\hline \multirow{2}{*}{ Sub-themes } & \multirow{2}{*}{ Codes } & \multirow{2}{*}{ 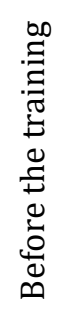 } & \multirow{2}{*}{ 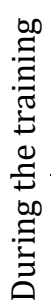 } & \multicolumn{9}{|c|}{ After the training } \\
\hline & & & & $\begin{array}{l}-1 \\
\tilde{n} \\
\tilde{\sigma} \\
\vec{v}\end{array}$ & $\begin{array}{l}N \\
\tilde{w} \\
\tilde{\Xi} \\
\tilde{U}\end{array}$ & $\begin{array}{l}m \\
w \\
\tilde{\sigma} \\
\tilde{v}\end{array}$ & $\begin{array}{l}+ \\
\sim \\
\tilde{\theta} \\
\tilde{U}\end{array}$ & $\begin{array}{l}n \\
\tilde{D} \\
\tilde{\sigma} \\
0\end{array}$ & $\begin{array}{l}0 \\
\tilde{心} \\
\tilde{\sigma}\end{array}$ & $\begin{array}{c}\hat{y} \\
\hat{\sigma} \\
\tilde{\sigma}\end{array}$ & $\begin{array}{l}\infty \\
\tilde{\omega} \\
\tilde{\sigma}\end{array}$ & $\begin{array}{l}a \\
\tilde{y} \\
\tilde{\theta} \\
\tilde{v}\end{array}$ \\
\hline \multirow{5}{*}{ The sources used in the class } & textbook & & & & & & & & & & & \\
\hline & Supporting source book & & & & & & & & & & & \\
\hline & Non-interactive e-book & & & & & & & & & & & \\
\hline & Geogebra materials & & & & & & & & & & & \\
\hline & Worksheet & & & & & & & & & & & \\
\hline \multirow{2}{*}{\multicolumn{13}{|c|}{$\begin{array}{l}\text { The technological tools used in the Interactive Board } \\
\text { class }\end{array}$}} \\
\hline & Tablets & & & & & & & & & & & \\
\hline \multirow{3}{*}{$\begin{array}{l}\text { Learning outcomes taken into } \\
\text { consideration during the class }\end{array}$} & Not taken into consideration & & & & & & & & & & & \\
\hline & Partially taken into consideration & & & & & & & & & & & \\
\hline & Entirely taken into consideration & & & & & & & & & & & \\
\hline
\end{tabular}

Melis used the text books and the supporting resources in all her courses. She checked the order of the subjects in the textbook and then picked up the necessary lectures on the topic and questions from the source book. According to her, the textbook is not sufficient in terms of the types of questions and content, and therefore she uses other books to bring a great variety of different questions to the class.

In the self-assessment form, applied during in-service training, Melis listed the sources books as the main source she relies on for the course and her classes. Moreover, she did not use the technological tools in her class before the inservice training. She noted in the interviews that she was not able to make the drawings she wanted on the interactive board because the "touchscreen" feature of the board was not good. This also disrupted students' attention. Therefore, she found it much easier to draw the figures on the white board with a board marker. During the in-service training, she used the e-book versions of the source books on the interactive board and Geogebra material. Throughout this process, she was regularly in touch with the IT teacher and had the technical features of the interactive board checked. She was asked to use a wireless mouse to avoid sliding while using Geogebra material with the interactive board. When Melis was evaluating the use of Geogebra software for the first time in her class, she stated that she would also allow students to use the software. In the nine classes observed after the training, it could be seen that the teacher used the interactive board and also encouraged the students to use the tablets. Moreover, after the training she used Geogebra materials in all her courses whereas she used the non-interactive e-books in all her courses except for class 3 . In addition, in class 3 Melis provided instructions on a separate worksheet to guide students when using their Geogebra material on their tablets.

In almost all classes of Melis, it was noted that she took the learning outcomes of the curriculum into consideration. While doing so, she also paid attention to the way subjects were presented in the textbooks sent to the schools by the Ministry of Education. Melis took the learning outcomes of class 6 only partially into consideration. This class focused on the dimensions of the cut and spring segments passing through the tangential points of the tangential circles internally and externally. This relationship can be explained through the tangent-beam angle. However, this relationship was not well explained in the curriculum or textbook. Melis noted that this was better explained in the source books and, therefore, she included the way it was explained in the source book in the content of the class. This shows again that the main source that Melis used in her lectures is supplementary source books.

\section{Knowledge of Students' Understandings and Learnings with Technology in Geometry}

This component is based on interviews, observations, field notes, and a self-assessment form on the teacher's knowledge about students' prior knowledge, and learning difficulties and the technological tools that can be used to identify and address these difficulties. This component is studied under the following themes: "taking students' prior knowledge and difficulties into consideration when planning the lesson" and "taking the students' prior knowledge and difficulties into consideration in the course work".

Before the training, Melis stated that she considered the students' prior knowledge when planning the lesson in advance. In the self-assessment form, she noted that in the classes she taught during the in-service period she took the level of the students into account when she was planning the class, and that she used the Geogebra material because it was difficult for students to visualize three-dimensional objects in their minds. In the interviews carried out after the 
training was completed, she stressed that she took the students' prior knowledge, planning difficulties, and learning difficulties into consideration in planning the course, and she added that she also gave a thought on how to benefit from technology to overcome student difficulties:

I look whether any student experiences difficulties and at the subjects that I have to repeat, and I also look whether there are any Geogebra materials on the topic. I think about the examples that I should give in the class and I pay attention to the class activities I need to organize (Melis-a).

Findings regarding whether the teacher takes into consideration student prior knowledge and difficulties in the classes observed are given in Table 7.

Table 7. The extent to which Melis considers a student's prior knowledge and difficulties in the course work

\begin{tabular}{|c|c|c|c|c|c|c|c|c|c|c|c|c|}
\hline \multirow[b]{2}{*}{ Sub-themes } & \multirow[b]{2}{*}{ Codes } & \multirow{2}{*}{\multicolumn{2}{|c|}{ 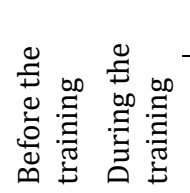 }} & \multicolumn{9}{|c|}{ After the training } \\
\hline & & & & $\begin{array}{l}-1 \\
\tilde{n} \\
\frac{\pi}{\omega}\end{array}$ & $\begin{array}{l}N \\
\tilde{n} \\
\frac{\pi}{U}\end{array}$ & 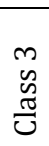 & 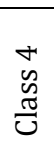 & 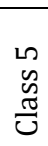 & $\begin{array}{l}0 \\
\tilde{y} \\
\tilde{c} \\
0\end{array}$ & $\begin{array}{l}n \\
\tilde{n} \\
\frac{\pi}{v}\end{array}$ & $\begin{array}{l}\infty \\
y \\
\tilde{y} \\
\frac{\pi}{U}\end{array}$ & 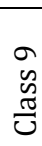 \\
\hline \multirow{3}{*}{$\begin{array}{l}\text { Taking the } \\
\text { student's prior } \\
\text { knowledge and } \\
\text { difficulties into } \\
\text { consideration }\end{array}$} & $\begin{array}{l}\text { Making a revision of the } \\
\text { previous class }\end{array}$ & & & & & & & & & & & \\
\hline & $\begin{array}{l}\text { Revealing the prior } \\
\text { knowledge }\end{array}$ & & & & & & & & & & & \\
\hline & $\begin{array}{l}\text { Using technology to address } \\
\text { student related difficulties }\end{array}$ & & & & & & & & & & & \\
\hline
\end{tabular}

Before the training, Melis used to revise the topics covered in the previous course as a strategy to warm up students before proceeding to the next topic, and she also checked students' prior knowledge on the topic to be covered. During the training process, she utilized the Geogebra material to overcome the difficulties that students have in visualizing three-dimensional objects. Melis stated in her self-assessment form that she considered the level of students, and she explained in detail the elements of the prism they learned in secondary school.

In the classes observed after the training, she started the class by revising the topic of the previous class. When doing these revisions, she sometimes used the Geogebra materials. In more than half of the classes observed after the training, she checked the prior knowledge of the students through asking questions. Especially when answering the sample questions related to the studied subject, the students solved the exercises only after they had been reminded about the Pythagorean Theorem, the properties of the isosceles right triangle, the properties of the square, the calculation of trapezium midsole length, and the edge properties of the triangle 30-60-90. Melis said that the students were having difficulty in establishing relationships when there was more than one geometry subject in the question. For this reason, she often made revisions with students and tried to use technology to overcome the difficulties that students had in their subjects in the light of the positive feedback she received for using Geogebra material in her class. After the training, Melis stated that the way she lectured caused difficulties for students in terms of understanding the topics and therefore she continued to use the software in other lessons and classes too:

In the past, for geometry classes, I would provide a definition of the concept examined. I would make comparisons orally without actually showing them anything. For instance, I would talk on the perpendicular geometric shapes but I was the one who was always active. They could answer the simple questions only after I had showed them a sample answer. I mean I was changing the numbers and they were solving it. They could not solve any exercises which had a higher level of difficulty. Now, I ask them to answer the questions before I offer them some guidance. I would previously have to push them to solve the problems on the board but now they can solve problems without my help (Melis-a).

\section{Knowledge of Instructional Strategies and Methods for Teaching Geometry with Technology}

In this theme, an interview, observation, field notes, and a self-assessment form were utilised to investigate which instructional strategies and methods related to technology Melis employs. This component is analysed under the themes of "instructional strategies used by the teacher", "teaching methods used by the teacher", and "teacher's level of technology use in her classes".

Melis stated that before the training she generally employed lecturing or the questions and answers technique in her class and added that she tried to involved students as much as she could in a problem-solving process:

I make a presentation and I ask questions to students. This is my way of lecturing; I ask a lot of questions such as what is that, how can we do this or that. I take their opinions and I encourage them to be as active as possible (Melis-b). 
When Melis was evaluating the class in which she used Geogebra for the first time, she stated in the self-assessment form that she used the presentation and the questions and answers technique. She explains some basic concepts through presentation and then employs the questions and answers technique to generalise the rules for other geometrical figures and to confirm that the students have comprehended the lecture.

After the training, Melis criticised herself and noted that her way of teaching before the training was ineffective and monotonous and that she tries to add the discovery strategy in her classes. To achieve this, she lets her students work on the tablets and follows more student-centered techniques. She defines herself as the one who guides students, and students learn through practice in the classroom:

In my last lessons, I taught them the circle subject. After the activity, I asked them to discover the relationships. They all discovered them on their own. They looked into what is circle angle, center angle, and beam angle. They came up with very nice ideas and comments. I wanted them to discover all these on their own, and they explained what they have found with their own words. It was very nice. They gained confidence when they saw that they can discover knowledge (Melis-a).

Findings obtained by analyzing the classes of Melis teacher in terms of the strategies and methods used by the teacher are presented in Table 8 in detail.

Table 8. Instructional strategies employed by Melis

\begin{tabular}{|c|c|c|c|c|}
\hline \multicolumn{2}{|c|}{$\begin{array}{l}\text { Observed } \\
\text { classes }\end{array}$} & Strategy & Method & Explanation \\
\hline \multicolumn{2}{|c|}{$\begin{array}{l}\text { Before the } \\
\text { training }\end{array}$} & Presentation & $\begin{array}{l}\text { Instruction, } \\
\text { Question and } \\
\text { answer }\end{array}$ & $\begin{array}{l}\text { Traditional Approach dominated. She used the white board, explained } \\
\text { the topic and then asked students to solve problems. }\end{array}$ \\
\hline \multicolumn{2}{|c|}{$\begin{array}{l}\text { During the } \\
\text { training }\end{array}$} & Presentation & $\begin{array}{l}\text { Instruction, } \\
\text { Question and } \\
\text { answer }\end{array}$ & $\begin{array}{l}\text { Traditional Approach Dominated. She provided the definition of prisms } \\
\text { using non-interactive e-book and then explained the topic in detail } \\
\text { through Geogebra materials. She asked students questions and used } \\
\text { technology to confirm if students grasped the topic. }\end{array}$ \\
\hline \multirow{9}{*}{ 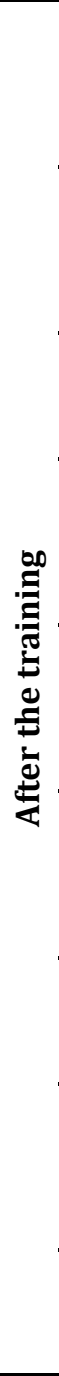 } & Class 1 & $\begin{array}{l}\text { Presentation } \\
\text { and Discovery }\end{array}$ & $\begin{array}{l}\text { Instruction, } \\
\text { Question and } \\
\text { answer, } \\
\text { Discussion }\end{array}$ & $\begin{array}{l}\text { Although she directly provided the definitions, she employed question } \\
\text { and answer technique using Goegebra materials. She also allowed } \\
\text { students to examine the materials on their tablets and therefore had a } \\
\text { constructivist approach. }\end{array}$ \\
\hline & Class 2 & $\begin{array}{l}\text { Presentation } \\
\text { and Discovery }\end{array}$ & $\begin{array}{l}\text { Instruction, } \\
\text { Question and } \\
\text { answer }\end{array}$ & $\begin{array}{l}\text { Although she tried to adopt constructive approach by using question } \\
\text { and answer technique on Geogebra material and allowing students to } \\
\text { use their tablets in the beginning of the class, traditional approach } \\
\text { dominated. There was no discovery process. }\end{array}$ \\
\hline & Class 3 & Discovery & $\begin{array}{l}\text { Question and } \\
\text { answer, } \\
\text { Discussion }\end{array}$ & $\begin{array}{l}\text { Constructive Approach was adopted and students were encouraged to } \\
\text { examine the materials on their tablets in a technology-supported } \\
\text { environment and worksheet with a list of instructions was provided. }\end{array}$ \\
\hline & Class 4 & Presentation & $\begin{array}{l}\text { Instruction, } \\
\text { Question and } \\
\text { answer }\end{array}$ & $\begin{array}{l}\text { Although she tried to adopt constructive approach by using question } \\
\text { and answer technique on Geogebra material and allowing students to } \\
\text { use their tablets in the beginning of the class, she directly provided the } \\
\text { knowledge. Thus, traditional approach dominated. }\end{array}$ \\
\hline & Class 5 & $\begin{array}{l}\text { Presentation } \\
\text { and Discovery }\end{array}$ & $\begin{array}{l}\text { Instruction, } \\
\text { Question and } \\
\text { answer, } \\
\text { Discussion } \\
\end{array}$ & $\begin{array}{l}\text { Although she tried to adopt constructive approach by using question } \\
\text { and answer technique and discussion on Geogebra material and } \\
\text { allowing students to use their tablets, traditional approach dominated. } \\
\text { There was no discovery process }\end{array}$ \\
\hline & Class 6 & $\begin{array}{l}\text { Presentation } \\
\text { and Discovery }\end{array}$ & $\begin{array}{l}\text { Instruction, } \\
\text { Question and } \\
\text { answer, } \\
\text { Discussion }\end{array}$ & $\begin{array}{l}\text { She tried to adopt constructive approach by using question and answer } \\
\text { technique on Geogebra material and allowing students to use their } \\
\text { tablets. Some activities were student centred yet traditional approach } \\
\text { dominated. }\end{array}$ \\
\hline & Class 7 & Presentation & $\begin{array}{l}\text { Question and } \\
\text { answer, } \\
\text { Discussion } \\
\end{array}$ & $\begin{array}{l}\text { She tried to adopt constructive approach by using question and answer } \\
\text { and discussion technique on Geogebra material and allowing students } \\
\text { to use their tablets. }\end{array}$ \\
\hline & Class 8 & $\begin{array}{l}\text { Presentation } \\
\text { and Discovery }\end{array}$ & $\begin{array}{l}\text { Instruction, } \\
\text { Question and } \\
\text { answer, } \\
\text { Discussion }\end{array}$ & $\begin{array}{l}\text { She explained some properties of Geogebra but she also asked students } \\
\text { to discover the rest on their Geogebra materials. }\end{array}$ \\
\hline & Class 9 & $\begin{array}{l}\text { Presentation } \\
\text { and Discovery }\end{array}$ & $\begin{array}{l}\text { Instruction, } \\
\text { Question and } \\
\text { answer, }\end{array}$ & $\begin{array}{l}\text { She explained some properties of Geogebra but she also asked students } \\
\text { to discover the rest on their Geogebra materials. }\end{array}$ \\
\hline
\end{tabular}


In the class observed before the training, it could be seen that Melis used the presentation strategy and the methods of instruction and questions and answers. The teacher started the class with a definition and rules and continued with sample questions. In other words, the teacher employed the traditional approach to teaching.

In the class observed during the training, it could be seen that Melis used the presentation strategy and instruction and questions-answers methods. The teacher started by giving definitions and explanations on the subject for which a presentation was also reflected on the interactive board. Later on, she provided explanations on prisms using Geogebra material. Geogebra material was also used to verify the information presented and to check the answers of the question. There was no change in the routines Melis applied in the class, and she continued to adopt the traditional approach.

In the classes observed after the training, it was seen that Melis used the discovery technique in addition to the presentation technique. Particularly in the third course, she allowed students to use a worksheet and tablets, and she employed the discovery technique to help students discover knowledge on their own. She also tried to use the discovery technique in the seventh class. This time, however, instead of using the worksheet, she asked questions on the materials in their tablets and initiated a classroom discussion so as the students to discover knowledge on their own. Therefore, in these two classes, it could be argued that Melis adopted a constructivist approach.

Even though Melis allowed the students to examine the material on their tablets by asking questions on Geogebra materials during the class 4 , it can be said that the traditional approach was dominant given that it was mostly Melis that provided the answers of the questions. This may be because the class focused on a revision of the previous classes and on solving questions.

In the first, second, fifth, and sixth classes observed after the training, Melis tried to use both the discovery and the presentation strategy. In these lectures, she used answer and question on Geogebra material to help students grasp the various concepts, and she tried to adopt the constructivist approach by allowing the students to examine the materials on their tablets. This was not, however, a process based entirely on discovery, and the traditional approach was dominant.

In the eighth and ninth class, Melis tried to use both the presentation and the discovery strategy. While some features were explained directly by the teacher in these lessons, the teacher also tried to encourage the students to explore the Geogebra materials on their tablets.

It is also important to understand how and for what purpose the teacher uses technology in her teaching strategies and methods. The findings related to the technology used before the training, during the training, and after the training are presented below.

In the classes before the training, Melis never used technology. She employed the presentation strategy using white board to deliver the lecture. Although Melis knew how to use the interactive board, if she was not prepared for the class she usually lectured in a traditional way. If she had some preparation, she would use the interactive board to project the questions on the screen. Figure 3 shows Melis' level of technology use in the class that was observed before the training.

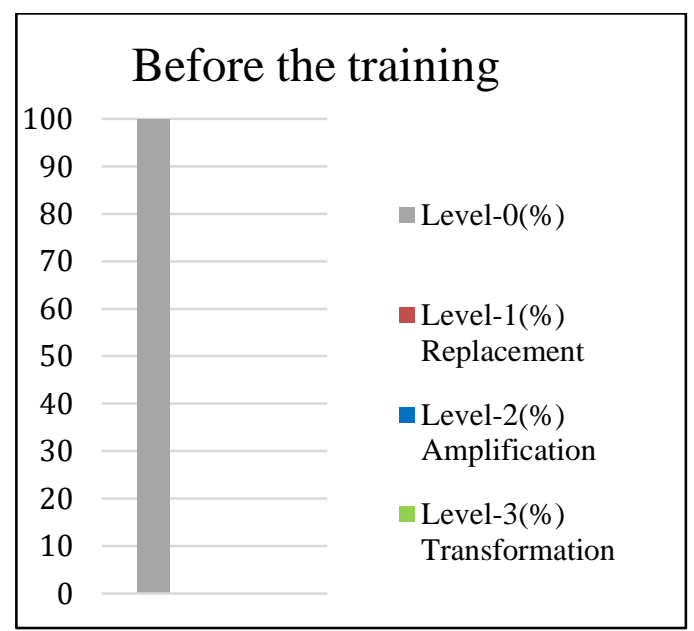

Figure 3. Melis' level of technology use before the training

Before the training, Melis said that she preferred not to use the interactive board because of some technical troubles whereas for her classes in the 20th grade, she added that she preferred to lecture the course using the traditional white 
board as she does not have any preparation. Prior to the training, it was seen that Melis' level of technology use was at the level-0 as she has never used it or in the cases when she had preparation for the class, it was at level 1 (Replacement) as she only used it to project the questions and lecture notes on the screen so that students can follow them.

During the training, Melis used the three-dimensional Geogebra material in her class to achieve the $10^{\text {th }}$ grade mathematics learning outcome of "understanding what creates the surface area relationships of steep prisms". Figure 4 shows Melis' level of technology use in the class that was observed during the training.

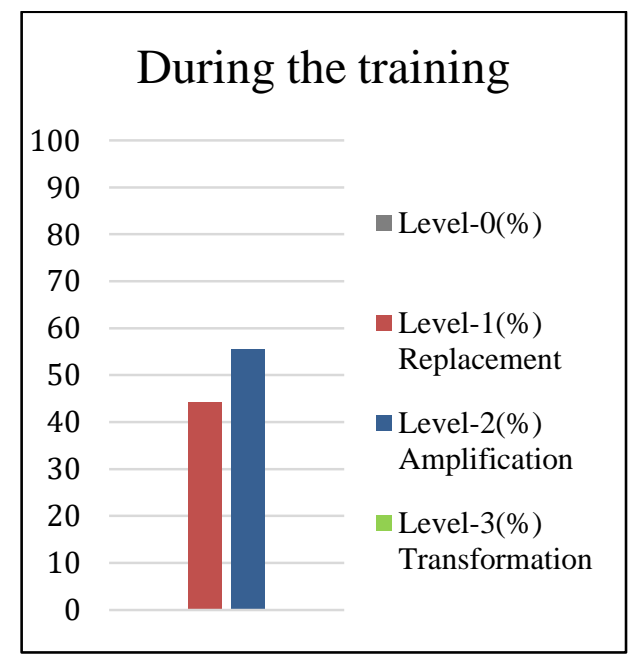

Figure 4. Melis' level of technology use during the training

During her training, Melis explained the basic concepts related to the topic, which were taken from the non-interactive resources book that she uses, through the interactive board and thus she used technology at the level of level 1 , which is utilising technology to change the environment. She used the Geogebra material on the interactive board to effectively explain the topic and to confirm that the students have understood the topic.

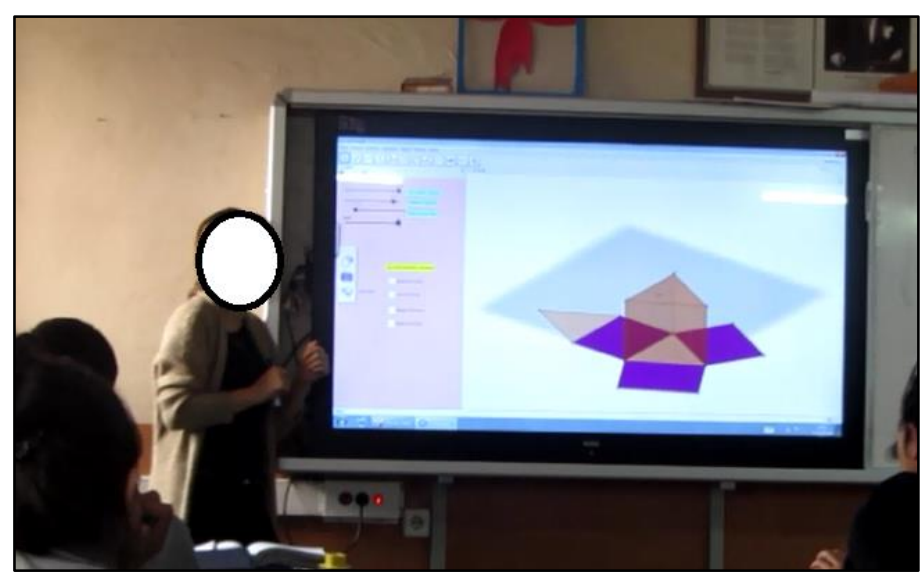

Figure 5. A photo shoot of Melis' class during the observation

Geogebra material was used only by the teacher on the interactive board, and the students did not use the tablets. The prisms in the prepared three-dimensional materials are opened and closed, enlarged to introduce the surfaces of the prism, and it was shown to students how to calculate the lateral area of the prism and the surface area. The students were asked to solve questions on area calculations and the answers were checked using Geogebra material. Melis increased her level of technology use to level-2 (Amplification) by using technology to explain the subject in a fast and effective manner and to show the accuracy of learned information.

In the nine courses observed after the training, it was determined that the level of technology use of Melis was generally at level-1 (Replacement) and level-2 (Amplification), and only at a few courses ( $3^{\text {rd }}$ and $7^{\text {th }}$ course), she reached the level 3 (Transformation). Figure 6 shows Melis' level of technology use in the classes that was observed after the training. 


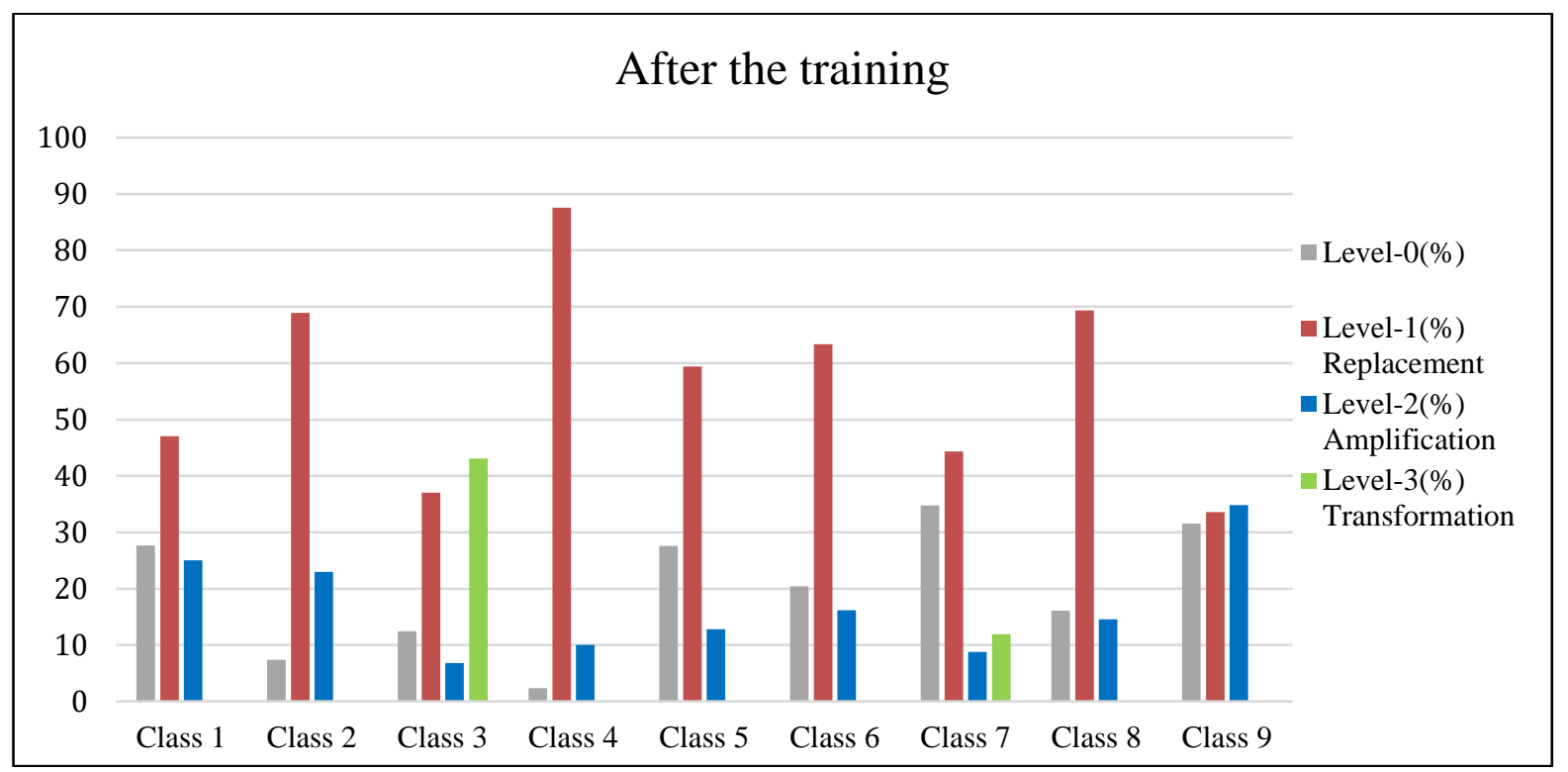

Figure 6. Melis' level of technology use in the observed classes after the training

After the training, it was also observed that Melis mostly allowed the students to use Geogebra software and tablets to give knowledge on the topic effectively, but in some of her, she also used the software to encourage the students to discover the relation between the concepts. Particularly on the third course after the training, she distributed worksheet and tried to make students discover the knowledge on the tablet by asking them to follow the guidelines on their worksheet. On the seventh class, she allowed student to use the Geogebra by asking guiding questions and encouraged them to discover the knowledge and learn it conceptually. This indicates that Melis changed her routines on $3^{\text {rd }}$ and $7^{\text {th }}$ classes and reached to the level 3 in technology use by undertaking student centered activities and using the Geogebra to discover the relations between concepts. A photograph of students trying to access information using tablets and Geogebra material is shown in Figure 7.

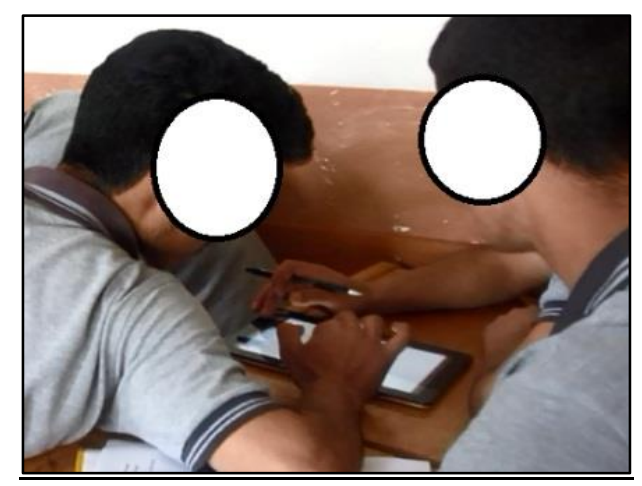

Figure 7. A photo shoot of Class 3

\section{Results and Discussion}

Before the training, Melis was using EBA as atechnological tool. Yet, after the training, she started to use Geogebra materials on interactive boards and tables as a technological tool. Both before and after the training, Melis noted that the use of technology in classes attracts the attention of the students, visually enriches the class and leads to permanent learning.

Some of the positive opinions that emerged during the training are that the use of Geogebra materials in lessons makes the lessons more entertaining, increases students' self-confidence and participation, and Geogebra materials help students discover the knowledge. These results are in parallel with the similar studies investigating the use of dynamic software in mathematics teaching (Kaleli-Yilmaz et al., 2010, Zengin and Kutluca, 2011; Verhoef et al., 2015; Mwingirwa and Milheso- O'Connor, 2016).

After the training, Melis stated that she received very positive feedback from students regarding the use of Geogebra on interactive boards and in tablets and this also increased her professional satisfaction. In addition, for her, being able to make desired changes on the Geogebra materials and design new materials is an advantage of this technology. 
In addition to all these positive opinions on the advantages of using technology, before the training, Melis pointed out that lack of time and the technical problems were the main reasons for not using the technology. Even after the training, her concern over the lack of time continued. It could be seen in the literature that this concern is also shared by many teachers (Forgasz, 2006; Kaleli-Yilmaz, 2012).

The inclusion of classroom observations in in-service training and the provision of teacher support when needed has allowed the teacher to gain experience in using technology in his class so that he can better understand the advantages of the technology and the potential disadvantages that may arise.

When Melis' development in the curriculum knowledge component is considered, it could be seen that the training increased her awareness on the interactive boards, tablets and dynamic softwares. She emphasized that it was only during the training that she noticed Geogebra activities in textbooks for the first time. Likewise, the studies in the literature show that in-service trainings increase the awareness of the teachers on the knowledge and communication technologies they can use in their classes (Niess et al., 2006; Kabaca et al., 2010; Yadigaroglu, 2014).

Melis started using the Geogebra material on interactive boards and non-interactive e-books. During the in-service training, she used the tablet for the first time in her classes and she also allowed students to use Geogebra material on their tablets. Contrary to this result, Pamuk et al. (2013) found in their classroom observations that almost none of the teachers used tablets in their classes at the time of the training or after the training.

Melis used the textbook to look at the order of topics, and she thought that the text book was insufficient in terms of content and question types, so she used the source books as the main textbook in her classes. This result is again similar to the results of the studies carried out by Nakiboglu (2009), Gokcek and Hacisalihoglu-Karadeniz (2013). The content Melis used in her classes was generally suitable for the curriculum and textbook. She indicated that she provided additional knowledge on the topic in the class as the source books included questions that could be useful for university entrance exams. Likewise, Gokcek and Hacisalihoglu-Karadeniz (2013) also identified that the secondary school students also used source books because of the questions related to the university entrance exams.

The review of the updated curriculum and textbooks with teachers and the teaching of the use of Geogebra software, which is also included in textbooks, has been influential in the development of the teacher's awareness of the resources recommended in the curriculum and the use of these resources.

When Melis' development in students' understanding component is looked into, it could be seen that both before and after the training she paid attention to the students' prior knowledge in planning her course. In addition, it was also noted in the class observations held after the training that she started to use Geogebra materials when revising the previous lesson's topics. Similarly, Kaleli-Yilmaz (2012) showed that some teachers started to use dynamic geometry software to revise the topics after the in-service training.

It was identified that after the training Melis paid attention on how to use technology to overcome the difficulties that students face when planning her class. She tried to show the mathematical relationships more effectively using the dynamics of Geogebra materials, and she continued to use Geogebra materials as she realized that students grasped the topics more easily. This result aligns with the study of Akkoc et al.'s (2011) on primary school mathematics teachers' use of technology to overcome student difficulties and their misconceptions during micro-teaching and school practices after the TPCK workshops.

The principles on how students might experience difficulties with the learning outcome to be taught and how to use the technologies in overcoming these difficulties was presented in in-service training, and the researcher has modeled this subject with sample events. These have influenced the development of the teacher within students' understanding component.

When Melis' development of instructional strategies are examined, it can be argued that Melis continued to use instruction (lecturing) and question and answer techniques and methods while using the Geogebra material for the first time in the class. This can be explained by the fact that teacher focused on the use of technology. When the literature is examined, it can be seen that many teachers try to use technology with their traditional teaching methods (Baki, 2002; Kaleli-Yilmaz, 2012; Bilici and Guler, 2016). After the training, it was noted that Melis had a more studentcentered approach by allowing her students to discover Geogebra materials on their tablets. In addition, she also started using discussion techniques to encourage students to share the results they have come accross by reviewing Geogebra materials.

When we look at the level of technology usage, Melis did not use technology in her classes before the training. However, interviews showed that she used the interactive board as a tool of presentation when she had a preparation. Research 
also support that teachers use technology for presentation purposes (Demir et al., 2011; Pamuk et al., 2013; Birisci and Calik-Uzun, 2014).

Support and observation of the use of Geogebra materials by interactive board and tablets in in-service training has been effective in improving the level of technology use. After the training, Melis increased her level of technology use to the amplification level by using Geogebra materials to run the learning process quickly and effectively and to demonstrate the truth of the learned information. In addition, in the two lessons following the training, she utilised technology at the highest level of transformation by giving students an opportunity to examine materials on their tablets and using technology to construct relationships and deep conceptual understanding of student-centered explorations. Students from the $10^{\text {th }}$ grade are recurrent students. This may have caused the use of technology at the level of transformation at a low level. Similar to the study of Akkoc et al. (2011), most mathematics teacher candidates did activities at the level of transformation in their courses even after a short period of time after TPCK workshops.

\section{Suggestions}

As seen in the results of the study, difficulties related to the technological hardware and the technical features of the software affect the use of technology by the teacher in a negative way. To address this concern, school management and the information technology teachers should regularly check and maintain the relevant hardware and software and support teachers.

Due to concerns about the adequate preparation of students for the university entrance exams, the teacher opts more for source books. These books provide more detailed explanations than the curriculum and focus more on solving problems. At the same time, the teacher is concerned about not having much time to use technological tools combined with a discovery strategy. To address this concern, it may be advisable to ensure that the questions in the university entrance exams are in line with the updated curriculum and textbooks.

When the teacher used technology in the classroom, it was seen that the feedback she received from the students influenced her planning for the next classes and shaped the subsequent initiatives related to the use of technology. This shows the importance of teachers' experiences of using new technologies in their classes. Therefore, teachers should be encouraged and supported to use technology in their classes in the future training sessions.

Before the training, Melis did not even know that there were textbook activities employing Geogebra software while through the training she developed an awareness on the recommended technological resources in the curriculum and she started to use these resources in her classes. In order for other teachers to apply the updated curriculum into their classes, the changes in the curriculum and the textbooks should be introduced in detail to teachers and examples should be given on how to apply the new elements in the classroom.

Geogebra software has been included in the course program as it is compatible with the Android operating system in the tablets, and the mathematics textbooks include activities related to this software. There are many dynamic software and learning objects that can be used in the teaching of mathematics and geometry. In particular, new applications can be added to the EBA system that teachers and students can access from their tablets. In this context, researchers working on technology integration can design in-service training programs that include different technological tools, software, and applications, and they can train teachers to use these technologies effectively in their classes.

The course program included only Geogebra materials in accordance with the geometry learning outcomes of the 9th and 10th grades. When the updated mathematics curriculum is examined, it is seen that the use of dynamic geometry software is recommended to achieve various learning outcomes, and Geogebra software is suitable for preparing class activities for most of the topics related to mathematics and geometry. Researchers who will conduct similar studies in the future may design in-service trainings on different topics and levels of study that will aim towards the TPCK development of teachers, and they can subsequently examine the effectiveness of these in-service trainings.

\section{References}

Akkoc, H., Ozmantar, M. F., Bingolbali, E., Demir, S., Basturk, S. \& Yavuz, I. (2011). Matematik ogretmen adaylarina teknolojiye yonelik pedagojik alan bilgisi kazandirma amacli program gelistirme [Developing Program to enhance technological pedadogical content knowledge of Preservice Maths Teachers] (TUBITAK Proje Raporu 107K531). Istanbul: TUBITAK.

Baki, A. (2001). Bilisim teknolojisi isigi altinda matematik egitiminin degerlendirilmesi [Evaluation of mathematics education in the light of information technology]. Milli Egitim Dergisi, 149, 26-31. 
Baki, A. (2002). Ogrenen ve ogretenler icin bilgisayar destekli matematik [Computer-assisted mathematics for learners and teachers]. Ankara: Ceren Yayinlari.

Baki, M. (2012). Sinif ogretmeni adaylarinin matematigi ogretme bilgilerinin gelisiminin incelenmesi: Bir ders imecesi calismasi [Investigating development of prospective primary teachers' mathematical pedagogical content knowledge: Lesson study] (doctoral dissertation). Karadeniz Technical University, Trabzon.

Bilici, S. \& Guler, C. (2016). Ortaogretim ogretmenlerinin TPAB duzeylerinin ogretim teknolojilerini kullanma durumlarina gore incelenmesi [Investigation of teachers' TPACK levels with respect to use of instructional technologies]. Ilkogretim Online, 15(3), 898-921.

Birisci, S. \& Calik-Uzun, S. (2014). Matematik ogretmenlerinin derslerinde etkilesimli tahta kullanimina iliskin gorusleri: Artvin ili ornegi [Mathematics teachers' views on interactive whiteboard use in their courses: A sample of Artvin province]. Ilkogretim Online, 13(4), 1278-1295.

Bozkurt, A. \& Cilavdaroglu, A. K. (2011). Matematik ve sinif ogretmenlerinin teknolojiyi kullanma ve derslerine teknolojiyi entegre etme algilari [Mathematics and classroom teachers' perceptions of technology use and integration into their instruction]. Kastamonu Egitim Dergisi, 19(3), 859-870.

Bozkurt, A., Koc, Y. \& Demir, S. (2013). TPAB cercevesinde matematik ogretimine bir teknoloji entegrasyon modeli ve uygulama ornegi [A technology integration and application model to the teaching of mathematics within the context of TPCK framework]. In: T. Yanpar-Yelken, H. Sancar-Tokmak, S. Ozgelen \& L. Incikabi (eds.), Fen ve matematik egitiminde teknolojik pedagojik alan bilgisi temelli ogretim tasarimlari [Teaching designs based on technological pedagogical content knowledge in science and mathematics education] (pp.183-200). Ankara: Ani Yayincilik.

Buyukozturk, S., Kilic-Cakmak, E., Akgun, 0. E., Karadeniz, S. \& Demirel, F. (2012). Bilimsel arastirma yontemleri [Research methods]. Ankara: Pegem Akademi.

Canbazoglu-Bilici, S. (2012). Fen bilgisi ogretmen adaylarinin teknolojik pedagojik alan bilgisi ve ozyeterlikleri [The pre-service science teachers' technological pedagogical content knowledge and their self-efficacy] (doctoral dissertation). Gazi University, Ankara.

Cochran, K. F., DeRuiter, J. A. \& King, R. A. (1993). Pedagogical content knowing: An integrative model for teacher preparation. Journal of Teacher Education, 44(4), 263-272.

Cox, S. \& Graham, C. R. (2009). Using an elaborated model of the TPACK framework to analyze and depict teacher knowledge. TechTrends, 53(5), 60-69.

Creswell J. W. (2013). Nitel arastirma yontemleri: Bes yaklasima gore nitel arastirma ve arastirma deseni [Qualitative inquiry and research design: Choosing among five approaches] (M. Butun \& S. B. Demir, translate eds). Ankara: Siyasal Yayincilik.

Demir, S. \& Bozkurt, A. (2011). Ilkogretim matematik ogretmenlerinin teknoloji entegrasyonundaki ogretmen yeterliklerine iliskin gorusleri [Primary mathematics teachers' views about their competencies concerning the integration of technology]. Ilkogretim Online, 10(3), 850-860.

Demir, S. \& Ozmantar, M. F. (2013). Teknoloji destekli matematik ogretiminde pedagojik prensipler [Pedagogical principles in technology-supported mathematics teaching]. In: M. Dogan \& E. Karakirik (eds), Matematik egitiminde teknoloji kullanimi [Use of technology in mathematics teaching] (pp. 1-25). Ankara: Nobel Yayinlari.

Demir, S., Ozmantar, M. F., Bingolbali, E. \& Bozkurt, A. (2011). Sinif ogretmenlerinin teknoloji kullanimlarinin irdelenmesi [An investigation of elementary teachers' use of technology]. In Z. Genc (ed), 5th International Computer and Instructional Technologies Symposium Proceedings Book (pp. 922-928). Elazig: Firat University Printing Office.

Earle, R. S. (2002). The integration of instructional technology into public education: Promises and challenges. Educational Technology Magazine, 42(1), 5-13. 
Egitim Reformu Girisimi [ERG]. (2014). Fatih projesi egitimde donusum icin bir firsat olabilir mi? Politika analizi ve onerileri. Istanbul: ERG Yayinlari.

Ergun, M. (1989). Egitimde bilgisayarlarin kullanilma zorunlulugu ve programlarin yeniden duzenlenmesi [The necessity of using computers in education and revision of programs]. In: Egitim Bilimleri Sempozyumu Bildiriler (pp. 112-118). Malatya: Inonu Universitesi Egitim Fakultesi Yayinlari.

Forgasz, H. (2006). Factors that encourage or inhibit computer use for secondary mathematics teaching. Journal of Computers in Mathematics and Science Teaching, 25(1), 77-93.

Gokcek, T. \& Hacisalihoglu-Karadeniz, M. (2013). Ortaogretimde matematik ders kitabi yerine alternatif kaynaklarin tercih edilme nedenleri [Reasons for choosing alternative sources instead of textbook at secondary education]. Turkish Journal of Computer and Mathematics Education, 4(1), 20-31.

Grossman, P. L. (1990). The making of a teacher: teacher knowledge and teacher education. New York: Teachers College Press.

Guzel, I. (2010). Turkiye, Almanya, Kanada ortaogretim matematik ogretim programlarinin karsilastirmali degerlendirilmesi [Turkey, Germany, Canada highscool mathemathics curriculum comparing] (master thesis). Zonguldak Karaelmas University, Zonguldak.

Hughes, J. (2005). The role of teacher knowledge and learning experiences in forming technology-integrated pedagogy. Journal of Technology and Teacher Education, 13(2), 277-302.

Keles, E. \& Celik, D. (2013). 2000-2010 Yillari arasinda bilgisayar teknolojileri ve egitimde kullanimlarina yonelik yurutulen hizmet ici egitim kurslarinin incelenmesi [Investigation of in-service training courses performed about computer technologies and their application in education between 2000 and 2010 in Turkey]. Journal of Instructional Technologies \& Teacher Education, 2(1), 164-194.

Kabaca, T., Aktumen, M., Aksoy, Y. \& Bulut, M. (2010). Matematik ogretmenlerinin Avrasya GeoGebra toplantisi kapsaminda dinamik matematik yazilimi GeoGebra ile tanistirilmasi ve GeoGebra hakkindaki gorusleri [Introducing the in-service mathematics teachers with the dynamic mathematics software Geogebra and their views about Geogebra]. Turkish Journal of Computer and Mathematics Education, 1(2), 148-165.

Kaleli-Yilmaz, G. (2012). Matematik ogretiminde bilgisayar teknolojisinin kullanimina yonelik tasarlanan HIE kursunun etkililiginin incelenmesi: Bayburt ili ornegi [Investigation of the effectiveness of the in-service training designed towards computer technology usage in mathematics instruction: Bayburt case] (doctoral dissertation). Karadeniz Technical University, Trabzon.

Kaleli-Yilmaz, G. (2015). Analysis of technological pedagogical content knowledge studies in Turkey: A meta-synthesis study. Education and Science, 40(178), 103-122.

Kaleli-Yilmaz, G., Ertem, E. \& Guven, B. (2010). Dinamik geometri yazilimi Cabri'nin 11. sinif ogrencilerinin trigonometri konusundaki ogrenmelerine etkisi [Dynamic geometry software of Cabri's influence on 11 grade students' to learn in trigonometry issues]. Turkish Journal of Computer and Mathematics Education, 1(2), 200-216.

Kilic, A. (2011). Fen ve teknoloji ogretmen adaylarinin elektrik akimi konusundaki teknolojik pedagojik alan bilgilerinin ve sinif ici uygulamalarinin arastirilmasi [Exploring pre-service science and technology teachers' technological pedagogical content knowledge and classroom practices involving the topic of electric current] (master thesis). Firat University, Elazig.

Magnusson, S., Krajcik, J. \& Borko, H. (1999). Nature, sources, and development of pedagogical content knowledge for science teaching. In J. Gess-Newsome \& N. G. Lederman (eds), Examining pedagogical content knowledge (pp. 95132). Netherlands: Kluwer Academic Publishers.

Miles, M. B. \& Huberman, A. M. (2015). Nitel veri analizi [Qualitative data analysis] (S. Akbaba-Altun \& A. Ersoy, translate eds). Ankara: Pegem Akademi. 
Milli Egitim Bakanligi [Republic of Turkey Ministry of National Education] [MONE]. (2011). Matematik ogretmeni ozel alan yeterlikleri [Mathematical special content competencies]. Retrieved March, 2, 2013 from http://otmg.meb.gov.tr/alan matematik ortaogretim.html

Milli Egitim Bakanligi [Republic of Turkey Ministry of National Education] [MONE]. (2013). Ortaogretim matematik dersi ogretim programi [Secondary school mathematics curriculum]. Retrieved October, 20, 2013 from http://ttkb.meb.gov.tr/www/guncellenen-ogretim-programlari/icerik/151

Milli Egitim Bakanligi [Republic of Turkey Ministry of National Education] [MONE]. (2016). Egitimde FATIH Projesi ogretmen egitimleri [FATIH Project in teacher training]. Retrieved Jume, 18, 2016 from http://fatihprojesi.meb.gov.tr/ ogretmen-egitimi/

Mishra, P. \& Koehler, M. J. (2006). Technological pedagogical content knowledge: A new framework for teacher knowledge. Teachers College Record, 108(6), 1017-1054.

Mwingirwa, I. M. \& Miheso-0' Connor, M. K. (2016). Status of teachers' technology uptake and use of GeoGebra in teaching secondary school mathematics in Kenya. International Journal of Research in Education and Science, 2(2), 286-294.

Nakiboglu, C. (2009). Deneyimli kimya ogretmenlerinin ortaogretim kimya ders kitaplarini kullanimlarinin incelenmesi [Examination on expert chemistry teachers' secondary school chemistry textbook usage]. Ahi Evran Universitesi Kirsehir Egitim Fakultesi Dergisi, 10(1), 91-101.

National Council of Teachers of Mathematics [NCTM]. (1989). Curriculum and evaluation standards for school mathematics. Reston, VA: Author.

National Council of Teachers of Mathematics [NCTM]. (1991). Professional standards for teaching mathematics. Reston, VA: Author.

National Council of Teachers of Mathematics [NCTM]. (2000). Principles and standards for school mathematics. Reston, VA: Author.

Niess, M. L. (2005). Preparing teachers to teach science and mathematics with technology: Developing a technology pedagogical content knowledge. Teaching and Teacher Education, 21(5), 509-523.

Niess, M. L. (2008). Guiding pre-service teachers in developing TPCK. In. AACTE Committee on Innovation and Technology (eds), Handbook of technological pedagogical content knowledge (TPCK) for educators (pp. 223-250). New York: Routledge.

Niess, M. L., Suharwoto, G., Lee, K. \& Sadri, P. (2006, April). Guiding inservice mathematics teachers in developing TPCK. Paper presented at American Education Research Association Annual Conference, San Francisco, CA.

Niess, M. L., van Zee, E. H. \& Gillow-Wiles, H. (2010). Knowledge growth in teaching mathematics/science with spreadsheets: Moving PCK to TPACK through online professional development. Journal of Digital Learning in Teacher Education, 27(2), 42-52.

Numanoglu, M. (1992). Milli Egitim Bakanligi bilgisayar destekli egitim projesi bilgisayar destekli ogretim ders yazilimlarinda bulunmasi gereken egitsel ozellikler [Computer aided education project: educational features in computer assisted instructional software] (master thesis). Ankara University, Ankara.

Ozkan, A. E. (2006). Turkiye, Belcika (Flaman) ve Singapur matematik ogretim programlari uzerine karsilastirmali bir calisma [A comparative study on mathematics education programs of Turkey, Belgium (Flemish), and Singapore] (master thesis). Hacettepe University, Ankara.

Pamuk, S., Cakir, R., Ergun, M., Yilmaz, H. B. \& Ayas, C. (2013). Ogretmen ve ogrenci bakis acisiyla tablet PC ve etkilesimli tahta kullanimi: FATIH Projesi degerlendirmesi [The use of tablet pc and interactive board from the perspectives of teachers and students: evaluation of the FATIH project]. Kuram ve Uygulamada Egitim Bilimleri, 13(3), 17991822. 
Patton, M. Q. (2014). Nitel arastirma ve degerlendirme yontemleri [Qualitative evaluation and research methods] (M. Butun \& S. B. Demir, translate eds). Ankara: Pegem Akademi.

Saralar, I. (2016). A pre-service mathematics teacher's technological pedagogical content knowledge regarding different views of 3-D figures in geometry (master thesis). Orta Middle East Technical University, Ankara.

Sezer, B. (2011, November). Bilisim teknolojilerinin egitime kaynastirilmasi: Onem, engeller ve ulkemizde gerceklestirilen projeler. Paper presented at XVI. Turkiye'de Internet Konferansi, Ege University, Izmir.

Shulman, L. S. (1986). Those who understand: Knowledge growth in teaching. Educational Researcher, 15(2), 4-14.

Timur, B. (2011). Fen bilgisi ogretmen adaylarinin kuvvet ve hareket konusundaki teknolojik pedagojik alan bilgilerinin gelisimi [The development of pre-service science teachers' technological pedagogical content knowledge in force and movement subjects] (doctoral dissertation). Gazi University, Ankara.

URL-1, http://fatihprojesi.meb.gov.tr/proje-hakkinda Egitimde FATIH projesi hakkinda [About FATIH project], cited 2017 February 23.

Usun, S. (2013). Bilgisayar destekli ogretimin temelleri [The foundations of computer assisted teaching] (3rd edition). Ankara: Nobel Yayinlari.

Valanides, N. \& Angeli, C. (2005). Learning by design as an Approach for developing sceince teachers' ICT-related pedagogical content knowing. In S. Rodrigues (ed), International perspectives on teacher professional development (pp. 79-101). New York: Nova Science Publishers.

Verhoef, N. C., Coenders, F., Pieters, J. M., Smaalen, D. \& Tall, D. O. (2015). Professional development through lesson study: Teaching the derivative using GeoGebra. Professional Development in Education, 41(1), 109-126.

Voogt, J., Fisser, P., Pareja Roblin, N., Tondeur, J. \& van Braak, J. (2013). Technological pedagogical content knowledge-a review of the literature. Journal of Computer Assisted Learning, 29(2), 109-121.

Yadigaroglu, M. (2014). Kimya ogretmenlerinin teknolojik pedagojik alan bilgisi modeli hakkinda bilgi ve becerilerini gelistirmeye yonelik hizmet ici egitim programi gelistirilmesi ve etkililiginin arastirilmasi [Developing an inservice training programme for improving chemistry teachers' knowledge and skills about technological pedagogical content knowledge model and investigating its effectiveness] (doctoral dissertation). Karadeniz Technical University, Trabzon.

Yildirim, A. \& Simsek, H. (2013). Sosyal bilimlerde nitel arastirma yontemleri [Qualitative research methods in social sciences. Ankara: Seckin Yayincilik.

Zengin, Y. \& Kutluca, T. (2011). Ortaogretim matematik dersinde Geogebra kullanimi uzerine ogretmen adaylarinin gorusleri [Prospective mathematics teachers' views on the use of Geogebra in secondary mathematics curriculum]. In Z. Genc (ed), V. International Computer \& Instructional Technologies Symposium Proceedings Book (pp. 679). Elazig: Firat University Printing Office. 